\title{
GRAHAM GREENE AND LEOPOLDO DURÁN: QUIXOTIC COMPANIONS ACROSS SPAIN AND PORTUGAL
}

\author{
Carlos Villar Flor \\ Universidad de La Rioja (Spain)
}

\begin{abstract}
It is well known that in his later years Graham Greene spent several summer holidays travelling around Spain and Portugal in the company of his friend Leopoldo Durán, a Galician scholar and Catholic priest. Starting in the summer of 1976, these yearly holidays consolidated their mutual friendship and provided inspiration for Greene's novel Monsignor Quixote (1982), which features several discussions on faith and belief based on their long chats and confessions. During these travels Durán got to know Greene very well and became one of his closest companions in the last stages of his life, and even accompanied him at his deathbed and administered the last sacraments to him.

Considering Durán's influence and how this friendship was forged mostly throughout the various Iberian journeys it is remarkable to note how few particulars about them are given in Norman Sherry's third biographical volume, covering from 1955 to 1991 . The official biographer has conducted no further research other than a few occasional references to Durán's memoir, Graham Greene, Friend and Brother (1994), which is the closest we get to a narrative of the trips. However, even this unique source declines to give a full chronological account of them and remains quite obscure in many respects. It is not only that the author offers a highly subjective and occasionally biased account of their "summer jaunts"; so far there exists no written account, either by Durán or by any other biographers, of the number, duration, stages or dates of Greene's Iberian trips. Therefore, this paper sets out to fill in this gap and to provide a reference framework for future research on this fascinating period of Greene's life.
\end{abstract}

Keywords: Graham Greene, Leopoldo Durán, Monsignor Quixote, Spain and Portugal, travel literature, Murrieta wine.

\section{Resumen}

Es bien conocido que, en sus últimos años, Graham Greene pasó varias vacaciones de verano viajando por España y Portugal en compañía de su amigo Leopoldo Durán, un sacerdote y estudioso gallego. Desde el verano de 1976, estas vacaciones anuales consolidaron su mutua amistad y suministraron información para la novela de Greene Monsignor Quixote (1982), en la que aparecen varias discusiones sobre fe y creencia basadas en sus largas charlas y confesiones. Durante estos viajes Durán llegó a conocer a Greene muy bien y se convirtió en uno de sus compañeros más íntimos en la última etapa de su vida, acompañándolo incluso en su lecho de muerte en donde le administró los últimos sacramentos. 
Teniendo en cuenta la influencia de Durán y cómo se forjó su amistad fundamentalmente a través de varios viajes ibéricos, es muy digno de notar qué pocos detalles particulares se dan acerca de estos viajes en el tercer volumen de la biografía de Norman Sherry que cubre el periodo de 1955 a 1991. Los biógrafos oficiales no han llevado a cabo subsiguientes investigaciones excepción hecha de algunas referencias a las memorias de Durán en Graham Greene, Friend and Brother (1994), que es la mayor aproximación de la que disponemos en relación a este viaje. Sin embargo, incluso esta fuente no da una relación cronológica completa de estos viajes y permanece bastante obscura en muchos aspectos. No se trata solo de que el autor ofrece una relación altamente subjetiva y ocasionalmente parcial de sus "summer jaunts", sino que hasta la presente no existen relaciones escritas, ni por parte de Durán ni por parte de otros biógrafos, del número, duración, etapas o fechas de los viajes ibéricos de Greeene. En consecuencia, este papel se propone llenar este hueco y aportar un marco de referencia para futuras investigaciones sobre este fascinante periodo de la vida de Greene.

Palabras clave: Graham Greene, Leopoldo Durán, Monsignor Quixote, España y Portugal, literatura de viajes, vino de Murrieta.

\section{Quixotic companions}

Born in 1917 in a small Galician village (Penedo de Avión, Orense), Leopoldo Durán Justo was ordained priest in Astorga in 1943, and later took three doctorates: in theology (Angelicum, Rome), English literature (King's College, London), and philosophy (Universidad Complutense, Madrid). In 1964 he wrote a letter to Greene asking questions arising from his dissertation on the treatment of priests in Greene's work. An epistolary relationship developed henceforth and eventually led to a personal meeting in August 1973 at the Ritz Hotel in London. They seem to have hit it off well from the start, since this first dinner lasted several hours and Greene and Durán engaged in some personal confidences (Durán, Friend and Brother 3-8).

Three years after their first meeting, Greene agreed to spend his first summer holiday in Spain under Duran's guidance in July 1976. He had such a good time then that the tradition of the yearly "picnics" was established henceforth, which basically consisted in varied car journeys with a high degree of improvisation and an even higher degree of wine drinking and passionate conversation on human and divine matters. Durán engaged one of his former students as their driver: he had to be completely sober while at the wheel and be able to speak good English and have a pleasant conversation to entertain Graham. He was jokingly referred to as “the third man" in Durán's accounts, and from 1976 to 1989 four such men rotated in that capacity, depending on their availability or acceptability. ${ }^{1}$

\footnotetext{
${ }^{1}$ Their names were Miguel Fernández, Aurelio Verde, Octavio Gil and José Ramón Losada. Greene includes the first three in his dedication of Monsignor Quixote (he had not met Losada yet).
} 
In Durán's words, these trips were "delightful jaunts in which we took our food with us and ate it in the fresh air of the countryside" (Durán, Friend and Brother 120). They slept at hotels, paradores (those historical and artistic staterun hotels in Spain), and monasteries, though Greene, driven by his perennial fear of boredom, insisted that they should not stay longer than one night at each place. They soon started creating yearly rituals, such as paying a compulsory visit to the Cistercian monastery of Osera, spending one afternoon in Las Reigadas with Señor Antonio Nogueiras -an aged and charismatic Galician wine-maker later immortalized as Don Diego in Monsignor Quixote- or staying at Greene's old friend Maria Newall's finca in Sintra until her death in 1984.

From the reading of Durán's memoirs and diaries, there seems no doubt that both men felt a deep affection and respect for the other. Their personalities were certainly contrasting and perhaps complementary. Greene was tall, sharp, worldweary and leftish, while Durán was squat, naive, idealistic and conservative; but their friendship was strong and ripened with age. Though Durán's tone in his memoirs is highly panegyrical -Greene is portrayed as "a man capable of making the most heroic sacrifices" (Durán, Friend and Brother 15), he cannot hide some darker aspects of the writer's personality, such as his periodical bouts of depression and ill-humour, or those highly offensive moods that resulted from an uneasy combination of too much alcohol and downcast spirits. One might feel tempted to read between the lines and hazard that their friendship -though undoubtedly sincere and strong- was not conceived in terms of equality. No matter how "modest" Greene could be (Durán, Friend and Brother 9), it was obvious that he was the celebrity and that his whims or phobias had to be complied with. Since Greene insisted that they should travel incognito, Durán relates episodes in which he acts as a sort of bodyguard scaring away nosy passers-by who happen to ask the impertinent question: "Is this the famous Graham Greene?" On other occasions their conversation drifts away angrily in matters that Durán must disagree with, such as Greene's rants against Pope John Paul II or his defence of birth control, but even then Durán prefers to calm him down rather than openly contradict his friend, especially after "whisky time" (from six pm onwards).

From some of Durán's side comments it can be deduced that in the 1980s he was going through a difficult period in his professional and academic life. He was a conservative Catholic priest teaching in a rather leftist faculty in a Spain going through the 'Democratic transition'. More than once had he suffered student's sit-down protests, and in 1986 he would be forced to retire against his will. Amidst these difficulties, his growing friendship with Greene was a godsend that, apart from its intrinsic personal values, enhanced his own public figure. Some statements in his memoir may not sound excessively modest or tactful: "I am writing this book because no one else knows the essential characteristics of the man as I do", he candidly states in his introduction, and later reproduces two of Greene's letters according to which Durán knows "more about what I am trying to do than anybody else in Europe", or "no one knows better [the] nature of [my work] and its source" (Durán, Friend and Brother xiii). 
Greene's biographers have not been too flattering when assessing his friendship with Durán. Michael Shelden describes the priest as "a character waiting to be used and Greene did not pass the opportunity" (397), while Norman Sherry affirms that Durán "needed Graham Greene - he was his claim to fame," and, observing that Durán often presents himself in his memoirs as "somewhat submissive", he concludes that "this was probably no more than a natural humility when in Greene's company" (Sherry 705). Such statements are contained at the end of an ambitious Chapter 48 of Sherry's third volume, "The Lamb and the Lion: What Did Greene Believe?", which explores the difficult issue of what was Greene's faith like in his final years. Obviously, such an attempt to judge someone else's inner conscience seems far too ambitious a task, even for an authorized biographer. Although not all Sherry's remarks about the Greene-Durán friendship might sound pleasant -like his contention that Greene needed "the yearly companionship of a priest to assure himself that he ha(d) faith" (Sherry 701), or his caricature of Durán as "Greene's very own travelling priest!" $(695)^{2}$ the biographer cannot deny the strong influence that Durán had on the writer's struggle to believe. He identifies the long after-dinner conversations described by Durán in his book as Greene's long “confessions going deep into the night [...] about faith and doubt and his faith and his doubt" (Sherry 681). And he quotes from a letter by Greene's old time friend, Michael Richey, who admits that Durán's presence was the "means of reconciling him to the practices of religion" (697).

Mark Bosco, author of an insightful book on Greene's theology, places the growth of Greene's affection for Durán in the context of the writer's taste for cultivating the friendship of "priest intellectuals -Bede Jarrett in the 1920s and 1930s, C.C. Martindale in the 1940s and 1950s, and Leopoldo Durán in the 1970s and 1980s", which is one more evidence of "his constant immersion in the theological developments of his Catholic faith" (Bosco 156). ${ }^{3}$ Even with these precedents, Greene's friends and close relatives seem to have been somewhat puzzled at first by his decision to spend his summer holidays in the company of a Spanish priest. Greene's letters around the time of the early picnics present Durán in a rather detached way. This is the case, for example, of one letter to Maria Newall dated 1 August 1977, immediately after the end of the second Iberian summer:

The Holy Father, myself and Michael got safely back to Madrid via a monastery in Badajoz and a parador in Guadalupe. I was nearly suffocated in the monastery in Badajoz by the Holy Father who inadvertently turned on in that very hot city the heating in my room

\footnotetext{
${ }^{2}$ When the mutual references in Durán's and Sherry's books are compared, it is easy to perceive that the two men may not have got along terribly well.

${ }^{3}$ Sherry adds one more clergyman to the list of close acquaintances: Archbishop David Matthew (1902-1975), who advised him about how to react to Cardinal Griffin's condemnation of The Power and the Glory, and became very close to Greene in the 1960s.
} 
and I didn't realize it until I had undressed and had to wander the corridors of the monastery seeking help because there seemed to be no way of turning off the heating. In the parador I was startled to receive a call from the Holy Father carrying his toothpaste and toothbrush and soap because he wanted to clean his teeth and wash his hair in my bathroom. I said surely you have got a bathroom and he admitted he had, but of course then he couldn't talk. All the same I love him dearly and he is immensely fond of you. (Greene, A Life in Letters 345-46)

Referring to him as "the Holy Father" (Durán does not seem to have been aware of this nickname) and his farcical characterization may not sound very flattering, although Greene presently admits that he loves him dearly. One year later, in 1978, he still explains the character of his Spanish friend to Catherine Walston in terms that present him in a slightly preposterous light: "I am off to Spain to spend my yearly fortnight with my only priest, Father Durán. (He has written a book in Spanish on my theology!)" (Greene, A Life in Letters 351)

However, as time went by and the two men saw more of each other, both in Spain and Antibes, a stronger affection and confidence seems to have progressively grown. In fact, Sherry discusses the degree of mutual dependence between both men and hints at the conclusion that Greene came to need Durán hopelessly. He ends the aforementioned chapter, "The Lamb and the Lion", by recording the account given to him in $1987^{4}$ by Vicente Cebrián, Count of Creixell. Cebrián, then recent owner of Bodegas Murrieta, had invited Greene to the main sites of his company and a few months later visited Greene at his home in Antibes. He observed the peculiar relationship between the two friends and noticed that "Leopoldo Durán would be in his bedroom until he went to sleep Graham Greene was often nervous about his conscience- he drank too much [...]. Durán gave him the night to pacify him with his confessions -he was a private priest Durán, a kind of midwife" (Sherry 704). The reproduction -we never know if too literal (mistakes included) or too free- of Cebrián's speech plus Sherry's gloss goes on for five pages, but the basic conclusion is that Greene was tormented by his sense of sexual sin and that from time to time "secret remorse often overwhelmed him. Now that Archbishop Matthew was dead, Father Durán was an absolute necessity, his final hope that the good Father could prevent him from being condemned" (Sherry 705).

This account, which Sherry finds "fascinating", is a far cry from the portrait of the artist as a believer that Greene gave of himself in one of the last interviews he granted. Conducted by professor John Cornwell for the Catholic journal The Tablet on 23 September 1989, the interviewer asked Greene, with an astonishing

\footnotetext{
${ }^{4}$ I have reasons to believe that Sherry got the year wrong. According to Durán, Creixell and his wife only visited Greene in Antibes once, in February 1988 (Durán, "Manuscritos inéditos" 57). It makes more sense that Sherry was invited in 1991, and by then the foundation that invited him must not have been "Fundación Creixell" but rather "Fundación Graham Greene", though it did not last long under that name, as we shall see below.
} 
un-English directness, about some very intimate aspects of his religious practice and morals. Asked about his reception of sacraments, Greene nonchalantly observed that just "to please Fr Duran I make a confession now -of about two minutes; although I've nothing much to confess at the age of 85 " (Thomson 126). Such detached disposition radically contradicts the picture painted by Cebrián of a tormented Greene seeking for sacramental absolution every troubled night. But a former secret agent would not let himself be so easily pumped for information. His own public testimony about the workings of his inner conscience seems at least as uncertain as Cebrián's attempt - he and Durán were no longer on good terms - at psychoanalyzing Greene from what he could eavesdrop from behind his bedroom door.

\section{Iberian journeys}

Greene and Durán's friendship, enormously important for Greene's experience of faith, developed and strengthened in the framework of the summer trips through the Iberian countryside. Consequently, a thorough biography of Greene should have included more details of their "quixotic adventures." Up till now there is no further published account of these travels other than the muddled narrative contained in Friend and Brother. Sherry's research adds very little to this memoir, with the exception of his (probably misdated) conversation with the Count, who searched for Sherry rather than the other way round, and Durán's memoir is used in Chapter 48 not so much for relating travel episodes but rather as reference material for analyzing Greene's sort of faith. Sherry admits that, when invited by Durán to visit the emblematic monastery of Osera, he declined the invitation because he was then engaged in finishing off the first volume and considered that the material related to Greene's Spanish tours was too far ahead to worry about it. ${ }^{5}$ At any rate, eighty-two more chapters and seventeen (or, most likely, thirteen) years later he didn't seem to have bothered much about documenting these journeys by using complementary sources.

But Durán's memoir is far from being an ordered chronicle of their yearly trips. On the contrary, the division into sections and chapters is rather impressionistic, and only exceptionally does he present the facts in the order he took them down in his diary. And when he does, and the reader takes pains to put them all in order, he may find some discrepancies and patent mistakes. ${ }^{6}$ On the

\footnotetext{
5 "I confess I had no idea of the height of the mountain that Greene's life would force me to climb", he states (Sherry 702).

${ }^{6}$ Durán makes some obvious mistakes in his account of the travels. For example, on pages 198 to 200 he describes the official reception organized by Madrid's mayor in 1980. These events lasted from 6 to 10 July, and afterwards the couple and their "third man", Aurelio, set off on their usual semi-improvised journeys. But a few pages later Durán solemnly states "On 9 July 1980 we were both in London" (Durán, Friend and Brother 263). Another example: on page 156 he starts a narrative of events covering at least three days, starting on "13-14 August 1984." But a little afterwards a new day begins, with new successive activities, that is again dated as 14 August (161).
} 
other hand, some important events that happened in those years and were direct consequences of their Spanish experiences are omitted, as is the case of the creation of the Graham Greene Foundation.

Here is the first published reconstruction of the calendar and stages of Greene's Iberian journeys.

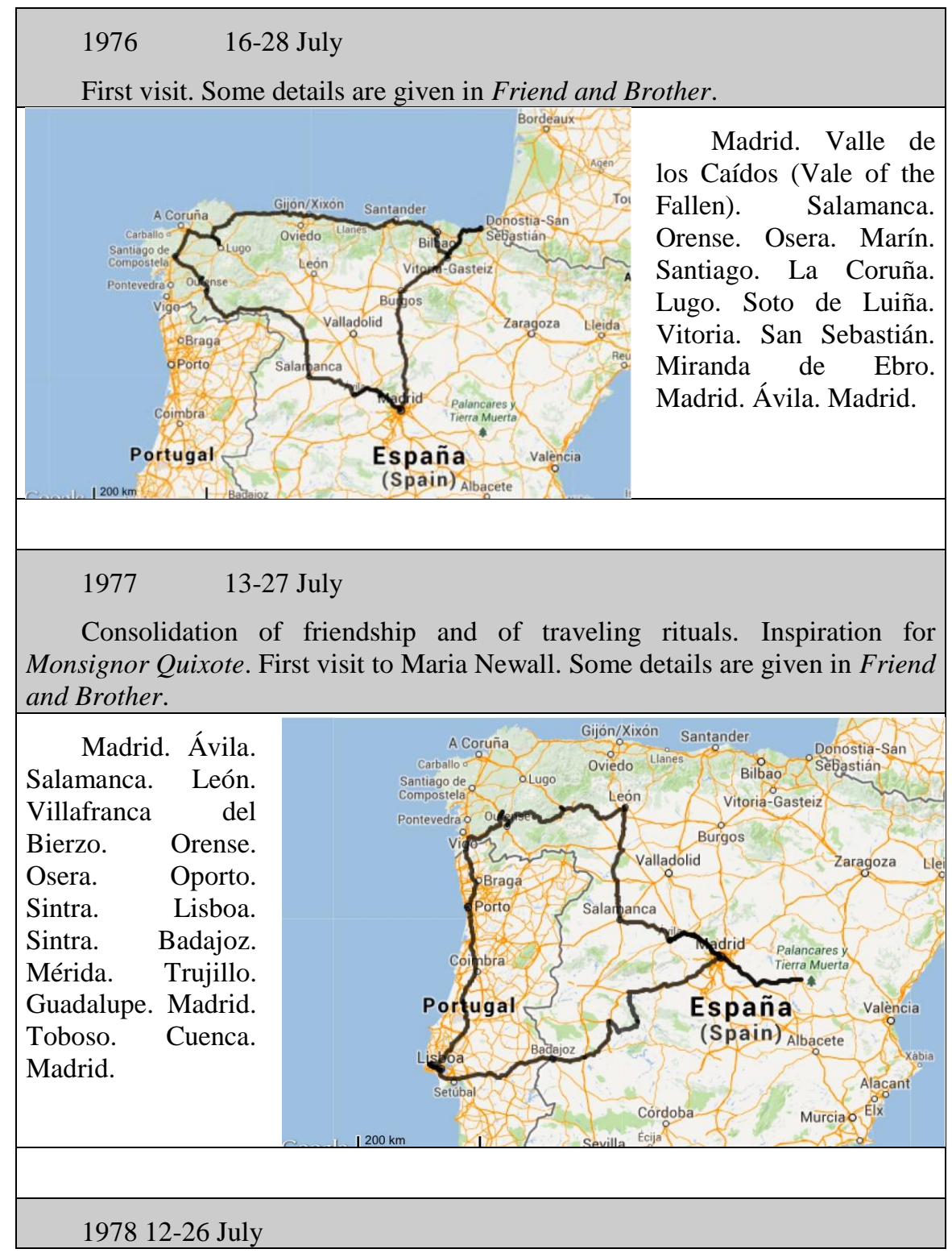


New rituals (such as visiting Las Reigadas), new "Third Man”. Monsignor Quixote constantly in mind.

Madrid. Navacerrada. Oropesa. Trujillo. Cáceres. Valencia de Alcántara. Pontealegre. Sintra. Lisbon. Coimbra. Oporto. Osera. Las Reigadas. Villafranca del Bierzo. Zamora. Salamanca. Segovia. Madrid.

\section{15-29 July}

First visit to Durán's hometown. Monsignor Quixote in mind.

Madrid. Oropesa. Mérida. Évora. Lisbon. Sintra. Fátima. Oporto. Osera. Las Reigadas. Vigo. Villafranca del Bierzo. Penedo de Avión. Madrid.

\section{6-25 July}

Official reception by Madrid's mayor Enrique Tierno Galván.

6-10 July, Official reception in Madrid. Then second stage (10-25 July) visiting the usual places: Oropesa. Evora. Lisbon. Sintra. Cascais. Lisbon. Sintra. Oporto. Las Reigadas. Penedo de Avión. Osera. Orense. Villafranca del Bierzo. Tordesillas. Salamanca. Madrid. Salamanca.

\section{3-15 July}

Looking for locations for scenes of Monsignor Quixote. Theological discussions.

Madrid. Tordesillas. León. Villafranca. Osera. Orense. Las Reigadas. Penedo de Avión. Osera. Benavente. Madrid. Cuenca. Salamanca. La Mancha. Valladolid. Galicia. Sintra. Oropesa. Madrid.

\section{3-12 January}

The only winter trip. Around Portugal mainly, so as to make up to Maria Newall, whom they did not visit in 1981.

Madrid. Mérida. Evora. Lisbon. Sintra. Oropesa.

1983 2-7 June

The shortest trip. No Portugal. First contact with Bodegas Murrieta.

Madrid. Logroño. Madrid. 
19843 VISITS: 23 April-2 May. 18-23 May. 9-18 August

First two visits to attend the filming of Monsignor Quixote [Detailed in Friend and Brother].

i) 23 April-2 May: Greene attends shooting of film Monsignor Quixote. First and only time Yvonne Cloetta (his mistress) comes along with him.

Toboso. Cuenca. Madrid. Salamanca. Ávila. Toledo. Madrid. Segovia. Madrid.

ii) 18-23 May. Last filming days.

Madrid. Santiago. Carballino. Osera. Santiago. Madrid.

iii) 9-18 August. Usual places. They learn that Maria Newall has died.

Oropesa. Plasencia. Béjar. Salamanca. Tordesillas. Orense. Las Regadas. Osera. Penedo de Avión. Osera. Cerdedo. Pontevedra. Cambados. Villagarcía de Arosa. León. Tordesillas. Arévalo. Segovia. Madrid. Aranjuez. Madrid.

\section{July-2 August}

[Detailed in Friend and Brother] "Too many churches"

Madrid. Silos. Aranda de Duero. Caleruega. Arlanza. Salas de los Infantes. Nájera. Logroño. Olite. Javier. Leyre. Roncesvalles. Valle del Roncal. Leyre. Liédena. Santo Domingo. Sigüenza. Madrid. Alto de los Leones.

1986 6-17 August.

The last "normal" trip.

Madrid. Oropesa. Plasencia. Béjar. Salamanca. Zamora. Osera. Las Reigadas. Cerdedo. Marín. Osera. Penedo. Osera. Puebla de Sanabria. Tordesillas. Madrid.

\section{4-12 August.}

Durán is now based in Vigo. Beginning of the Graham Greene Foundation ("the worst of our journeys together"). Guests of the Counts of Creixell in Ygay Palace (near Logroño) and Pazo de Barrantes. All the other expenses are paid for by the Count. [Completely omitted in Friend and Brother]

Madrid. Burgos. Logroño. Burgos. Puebla de Sanabria. Verín. Orense. Carballino. Pontevedra. Barrantes. Vigo. Reigadas. Osera. Vigo. Santiago. 


\section{8}

No trip.

\section{25-31 March.}

Last visit. Greene exhausted and aged. Durán wishes to finish off the Foundation, and this visit is kept from Creixell. A different "third man" (or woman) for each day. Some details of the trips are given in Friend and Brother.

Madrid. Vigo. La Guardia. Monte Tecla. Tuy. Vigo. Osera. Las Reigadas. Vigo. Viana de Castelo. Vigo. Madrid.

Obviously, this mere outline of the journeys, their duration and stages cannot display the many experiences their protagonists lived through. Durán's memoir relates a great number of such, and, "ludicrous though some passages may appear to be, Durán's book gives a revealing insight into Graham's instinctive piety" (Sherry 697) and also insights into some key aspects of Greene the writer. Perhaps the most telling anecdotes in this respect are those concerned with the genesis of the novel Monsignor Quixote. As is well known, this novel, a minor masterpiece of Greene's late period and highly significant of his religious development in the shade of post-Vatican spirituality, would not have existed if it had not been for his trips with Durán. Friend and Brother offers a lively account of a few experiences that triggered off some of the most significant events in the novel: the disaffected tone of the cemetery's official when asked about Unamuno's tomb, the origin of the allegory of the Trinity based on three bottles of wine -two of them full and the third half-empty, or the episode of the accidental turning on of central heating on a hottest night at a monastery in Badajoz (Durán, Friend and Brother 212, 214-15, 141-42 respectively).

\section{On the track of Murrieta ${ }^{7}$}

Surely one of the most interesting episodes connected with Greene's Spanish summers is the creation, decline and fall of the short-lived Graham Greene Foundation. Its interest increases when confronted with the fact that Durán never recorded any of the events relating to this story in his memoir, even though (or perhaps precisely because) he felt very deeply about them.

\footnotetext{
${ }^{7}$ Durán says in the introduction to his book: "I never knew whether I would ever write this book, even though Graham suggested two or three possible titles: '(Further?) Travels with a Donkey', parodying the one used by his distant relative, Robert Louis Stevenson; or 'On the Track of Murrieta', which alluded to one of our favourite wines..." (Friend and Brother xii-xiii).
} 
In 1983 Greene and Durán were invited to visit Ygay Palace, near Logroño, the major site of Bodegas Murrieta, on account of a couple of references to Greene's favourite red wine appearing in Monsignor Quixote (Greene 63, 64) This seemed just a simple act of gratitude on the part of the Olivares family, descendants of the original Marquis of Murrieta, and Greene and Durán enjoyed a generous dinner party and secured their supplies of Murrieta wine for the immediate future.

But the ownership of the Bodegas soon changed hands, and Vicente Cebrián, count of Creixell, took over from the Olivares family. Cebrián approached Durán, befriended him, and eventually suggested that he should bring Graham over again to visit the place that now belonged to him. Greene finally accepted after more than one year's insistence, and he and Durán reached Ygay Palace on 4 August 1987. Cebrián treated them exquisitely, presented Greene with a Gran Reserva from 1904 ("it keeps fitter than me", Greene commented) and when the time was ripe (that is, after "whisky time") he fired away. This is how Sherry dramatizes the scene:

COUNT: Your novels are very important in the world.

GREENE: Your wine is very important in the world.

COUNT: I should like to create a foundation which would bear your name.

GREENE: I should be delighted if this would give Leopoldo Durán a pension when I die. (Sherry 703)

Ten years later, Durán recounted this moment in a newspaper article with slightly different nuances:

After a little nap, Vicente asked Graham Greene's permission to create a foundation bearing his name. Greene's face darkened. He asked the count: "Is this for the sake of publicity?" "Neither your books nor my wines need publicity. But here is your great friend Leopoldo, who must keep on studying your work. He would become the president, of course. We will create a lifelong scholarship for him."

This was something completely unexpected... But Greene agrees, more with his silence than with words. (Durán, "Manuscritos inéditos" 52 [my translation])

A signed entry by Greene remains in the visitor's book of Palacio Ygay. It says:

\section{Dear Vincent}

This is a letter to a new friend who in the course of one day has become an old friend. I seemed to know you and your family long before we met, for Leopoldo has spoken of you so often. Now I have been able to see with admiration what you are achieving. But above all I love you for the help and encouragement you have given to Leopoldo 
at a very difficult period in his life. Retirement is the most deadly of all diseases. It kills more people than cancer. You, like a writer, will never retire. We are lucky; you have used this luck to help the unlucky which alas! I have not done.

With affection from a new member of your family,

\section{Graham Greene}

\section{August 1987}

If it was indeed written after Graham's silent agreement, it certainly shows that his main concern was to remind the Count that he should keep his promise to provide for Durán.

But six months later, when the trustees gathered at the notary's office to sign the foundation's deed, it turned out that Cebrián featured as the president and Durán as just the secretary. This was not what had been promised. For some reason, maybe a belated reaction, Durán signed, but later he protested and insisted they should meet again and sign a new deed. In the meantime, aware that Greene had not yet given a written agreement to the Foundation, Cebrián prevailed on Durán to make Greene invite the Counts over to his home in Antibes. Off they went on 19 February 1988. According to Durán, this stay in Antibes was the second and last time Greene and Cebrián ever met. ${ }^{8}$ They spent a few days of friendship and good will (though the Count would later complain to Sherry that Greene, who was the Count's guest for the whole duration of the previous summer holiday, never footed a single restaurant bill). Greene eventually complied with Cebrián's wishes by writing a highly non-committal letter to Durán:

Dear Leopoldo,

\footnotetext{
${ }^{8}$ This is a very important fact, because if it is true it turns Creixell's account in Sherry's book inaccurate. Sherry says he visited Galicia in 1987, and Creixell had already been in Antibes. As said above, it is likely that Sherry got this wrong, and the real year is 1991. On the other hand, Sherry reproduces Cebrián's statement that he spent "seven days in Graham Greene's company" (Sherry 704), which openly contradicts Durán's contention, unless Cebrián is counting the total number of days he spent with the couple in Ygay, Pazo de Barrantes (August 1987) and Antibes (February 1988) altogether. Finally, Sherry also quotes Cebrián saying that "the last time he [Greene] was here, in January 1987 he drank about 6 bottles of Marques de Murrieta" (704). As we can see, the two versions are strongly in conflict.
} 
It is with pride and pleasure that I have received news of your Foundation. Spain was the first foreign country I was first in at the age of 16 - at Vigo \& Corunna where a very distant ancestor of mine lies in his tomb - Sir John Moore.

I find quite inexplicable the important part which Spain has played in my literary career. My first (never published) novel dealt with the Spanish refugees in London during the Carlist wars. My third published novel (a very bad one) had as its scene Navarre during these wars. Since then among my later books four are based in Spain or Spanish [sic] America.

I wish the Foundation every possible good wish,

Graham Greene (reproduced in Azancot, "Fundación Graham Greene" 37)

Backed up by this hazy document, the Graham Greene Foundation could see the light. Its launching was publicly announced on the newspapers in July 1988, and Durán himself wrote a long article for the newspaper $A B C$ commending the initiative and its founders: ${ }^{9}$

I am returning from Antibes for the second time. On this occasion I was fortunate enough to be accompanied by the Counts of Creixell, Vicente Cebrián and doña María Jesús Suárez-Llanos, true friends. Two days with Graham Greene. He writes the carta magna of the foundation bearing his name. My friends are the inspiration and the providence of this enterprise. (Durán "Anecdotario secreto" vii [my translation])

Such words of praise might seem extravagant, considering the eventual outcome, but they are characteristic of Durán's "romance" with the Counts. Indeed, for more than one year Durán was over the moon about them: he became a sort of adopted uncle of this aristocratic family, attended Murrieta exhibitions, administered first communion to one of their daughters, spent several days at either of their palaces (Ygay and Barrantes), put their libraries in order, etc. His diaries of this time, between June 1987 and October 1988, show his infatuation with expressions such as: "Vicente and María Jesus are my angels in life", "They have been sent by Providence", and so on (Durán, Diaries XIII 125).

But things did not turn out as expected, and Durán and Cebrián soon fell out. Two different versions have been given, each one in turn a compound of different motives.

\footnotetext{
${ }^{9}$ Durán was a remarkably slow-paced writer, so the delay might not be entirely blamed on the newspaper.
} 
According to Durán, although the trustees did sign a second foundation deed in which he featured as the president, his real power was nil, so he could not foster the intended aims of the foundation. On the contrary, he understood that Cebrián's real objectives were mainly commercial: in December 1988 the Count set up an exhibition-sale of Murrieta wines in Sotheby's, using Greene's name as an effective advertising gimmick. When Greene heard of this he was upset. The Foundation did not mean a thing to him, he had only given his consent because he saw that his friend Leopoldo was enthusiastic and, most importantly, because the Count had promised to provide for Durán and thus solve his financial problems after his forced retirement. But neither was Durán receiving any salary nor was the Foundation carrying out the expected literary or research activities. Thus, on Durán's insistence, Greene wrote a stern letter dated 22 July 1989 finishing off the foundation as far as the use of his name was concerned. This letter remained unpublished, but it was Durán's leverage. Nine months later, "thanks to the Countess María Jesús Suárez Llanos, an extraordinary person," (Durán, "Manuscritos inéditos" 52) the Graham Greene Foundation started the long bureaucratic process of dissolution and eventually became "Creixell Foundation."

The other version, Norman Sherry's rendering of his private conversation with Cebrián, implies that when the foundation (that is, Cebrián) wanted to widen the scope and bring students in, Durán opposed. Besides, Durán might have resented that the Count was too friendly with Graham and that this could have threatened his own position as Greene's best friend. This is, in my view, a highly subjective argument against Durán, and is contradicted by the genuine expressions of affection and gratitude that Durán applies to the Count in his diaries (which Sherry didn't read, of course) over those months he had a disproportionate attachment to the Counts.

Finally, according to Sherry another reason behind the split-up was that Durán offered to sell some Greene documents to the Count at a heavy price (703). There must be something to it, since Greene wrote to his friend on 26 March 1989 reminding him that the manuscripts given by him remain Durán's and not the foundation's (Durán, "Manuscritos inéditos" 52), but this third storyline is left unfinished in Sherry's rendering. It is hard to understand how the offer of a commercial operation might have possibly annoyed a thoroughbred businessman such as the Count.

Durán's Friend and Brother came out in 1994, and it contained no single reference to this unpleasant story. Durán either wanted to avoid any possible libel actions if he spoke his mind, or rather preferred to let sleeping dogs lie. But two years later the Count died unexpectedly, still in his late forties, and soon afterwards a misinformed article in $A B C$ stated that Cebrián had been a close friend of Greene's, still called his organization "the Graham Greene Foundation", and praised its noble aims of furthering research on Greene's work. Durán was upset when he read this news and eventually wrote a fiery reply disclosing all the facts he had omitted in his book. Or rather, 'some' of the facts; his diary entries referring to the Count after the split-up still remain unprintable. 


\section{Conclusion}

Episodes such as the creation and dissolution of the Graham Greene Foundation indicate that there is still some considerable biographical material connected with Greene's Iberian travels that awaits further research. Durán's testimony of what happened during these fifteen visits (no commentator had so far counted the trips) is evidently partial, on the one hand for the obvious reason that human memory is selective and biased, much more so if it works its way into a memoir book meant to become a bestseller; on the other, because Durán must have felt that there were some stories too personal or too sensitive to be told, and some that could bring about unpleasant reactions on those who had taken part in them not so long ago. In turn, Greene's biographers so far have not taken enough interest in these trips as to use complementary sources for their research. Sherry, who admittedly felt too overburdened to conduct any further investigation after a quarter of a century following in Greene's footsteps, draws on Friend and Brother and on a casual testimony from Vicente Cebrián, who had by then fallen out with Durán and could not be excessively objective. As for Shelden, he has just complemented his bird's eye reference to Friend and Brother with Durán's interview for the BBC conducted by Donald Sturrock in 1992 (Shelden 397), which does not differ significantly in tone and content from the book that Durán was then writing.

In order to draw a more complete picture of the significance of Greene's Iberian travels new sources must be used. It would be illuminating to count on the testimonies of the 'third men', something which has never been done so far. Although most of them worked in academic jobs, none of them has ever published a personal account of the journeys they took part in. Other possibilities are opened up since 2012, after Georgetown University acquired Durán's papers on Greene, which are now kept at the Special Collections Research Center. Forty-eight boxes containing, among other things, Greene's correspondence with Durán, the priest's seventeen diary notebooks and some interesting Monsignor Quixote material.

The present essay lays down the basis for future scholarship on the subject, since it arranges the different journeys in chronological order for the first time and provides details of their duration, itineraries and dates. An exhaustive follow-up study of each of them can supply new biographical information enriching our knowledge about one of the most popular writers of the 20th century. In these relaxing jaunts around Spain and Portugal Greene spoke his mind about many different subjects: his latest or past books, his numerous travels all over the world, the public figures he had met and even befriended, several political issues, his attitude towards the Catholic faith and doctrine, philosophical discussions, his perceptions of the literary and publishing world, his relationships with acquaintances and friends, fascinating anecdotes... All these references might introduce new perspectives to improve our understanding of the complex 
personality of a writer so much in love with 'the dangerous edge of things'. It is surely worth looking into. ${ }^{10}$

\section{WORKS CITED}

Azancot, Nuria. "Fundación Graham Greene: el poder y la Gloria de una iniciativa única en el mundo". ABC 28 July 1988: 37. Print.

Bosco, Mark. Graham Greene's Catholic Imagination. Oxford: Oxford University Press, 2005.

Durán, Leopoldo. "Anecdotario secreto de mi amigo". ABC Literario 16 July 1988: vi-vii. Print.

---. Graham Greene, Friend and Brother. London: HarperCollins, 1994.

---. "Greene: Manuscritos inéditos de la verdad". ABC 11 July 1997: 52.

---. Unpublished Diaries, Special Collections Research Center, Georgetown University, Box 43.

Greene, Graham. Monsignor Quixote. London: Penguin, 1983.

Greene, Richard, ed. Graham Greene: A Life in Letters. New York: W.W. Norton, 2007.

Shelden, Michael. Graham Greene: The Enemy Within. London: Random House, 1994.

Sherry, Norman. The Life of Graham Greene,Volume 3: 1955-1991. London: Jonathan Cape, 2004.

Thomson, Ian, ed. Articles of Faith: The Collected Tablet Journalism of Graham Greene. Oxford: Signal Books, 2006.

${ }^{10}$ The author wishes to thank Ramón Rami Porta and Colin Garrett for their useful suggestions and insightful comments.

Received: 20 March 2015

Accepted: 26 June 2015 